\title{
Revista \\ Triângulo \\ O TUTOR NA EAD: QUEM É ESSE SUJEITO?
}

THE TUTOR IN EAD: WHO IS THIS GUY?

\author{
Hercules Guimarães Honorato ${ }^{1}$ e Débora Borges Lima ${ }^{2}$
}

\begin{abstract}
RESUMO
O objetivo deste estudo é analisar a importância do tutor na Educação a Distância por intermédio dos múltiplos olhares dos alunos cursistas, professores de português da rede estadual de educação, em formação continuada e realizando curso de extensão em Língua Portuguesa. Para melhor compreendermos os aspectos relacionados a esta nova atribuição docente, foi realizada uma pesquisa de cunho qualitativa, bibliográfica exploratória, apresentando os principais conceitos pertinentes a este campo profissional, contando ainda com a apresentação dos resultados finais de um levantamento, via survey online, com os referidos cursistas, visando conhecer que valores e olhares eles atribuem aos tutores nesta modalidade, respondendo a pergunta: quem é esse sujeito? Os resultados apontaram para o importante papel desenvolvido pelo professor-tutor, pois além das dimensões motivacionais para a construção dos conhecimentos, os discentes destacaram a importância na parte mais operacional de como buscar as informações e executar tarefas dentro do ambiente virtual.
\end{abstract}

PALAVRAS-CHAVE: Educação a distância. Tecnologias Digitais de Informação e Conhecimento. Tutor.

\section{ABSTRACT}

The aim of this study is to analyze the importance of the tutor in distance education through the multiple perspectives of pos-graduating students, teachers of public schools, doing an extension course in portuguese language. To better understand the issues related to this new teaching assignment, a qualitative research, literature exploratory was performed, presenting the main concepts relevant to this professional field, still relying on the presentation of the final results of an online survey, with the pos-graduating students, aiming to know which values and looks they assign to the tutors in this mode, answering the question: who is this tutor? The results pointed to the important role played by the teacher-tutor, because besides the motivational dimensions for the construction of knowledge, the students highlighted the importance at the operational part of how to seek information and perform tasks within the virtual environment.

KEYWORDS: Distance education. Digital Technologies of Information and Knowledge. Tutor.

\section{INTRODUÇÃO}

A sociedade atual encontra-se num período de transição, considerada como uma revolução global que está em curso, em especial no modo como pensamos sobre nós mesmos e no modo como formamos laços com outros (GIDDENS, 2003), o que poderíamos denominar de redes. Diante deste cenário, esta sociedade está vivendo profundas mudanças

\footnotetext{
${ }^{1}$ Superintendente de Ensino da Escola Naval (EN). E-mail: hghhhma@gmail.com

${ }^{2}$ Docente na Prefeitura Municipal de Duque de Caxias. E-mail: debora.limaaaa@gmail.com
} 
nas práticas culturais, políticas e econômicas, e que MILL (2012, p.137) afirma "que uma dessas mudanças se vincula à emergência de novas maneiras dominantes pelas quais experimentamos o tempo e o espaço".

Nessa nova relação de tempo e espaço, surge uma modalidade de educação: a "virtual", uma capacidade infinita de descobrir e reinventar o conhecimento, que no nosso caso, o educacional. Com a expansão da modalidade da Educação a Distância (EaD) e suas relações com as Tecnologias Digitais da Informação e Comunicação (TDIC), por muitas vezes, de forma reducionista, alguns autores tratam o tema como uma revolução tecnológica, em que as TDIC são as protagonistas exclusivas dessa revolução, sem considerar os desmembramentos pertinentes ao campo da educação.

Além das TDIC, o advento da Internet nos anos 1990 proporcionou um desenvolvimento no âmbito educacional, incluindo a modalidade da $\mathrm{EaD}$, e em nosso estudo a caracterização da docência contemporânea, em especial a "docência virtual", e que será tratada a seguir.

Caminhando em paralelo, o docente, de qualquer formação ou local de trabalho, deparou-se com limitações de concepção entre o conhecimento técnico-científico e a prática da sala de aula. Estudos foram gerados a partir da necessidade da superação dessa relação, visando outras possibilidades voltadas à profissionalização, buscando a compreensão da especificidade e da constituição dos saberes e formação docente, em especial os ligados ao profissional que ensina nesta modalidade, geralmente denominados "tutores".

O presente estudo teve como objetivo principal avaliar a importância do tutor no ensino a distância, na visão do professor cursista. Para isso, realizamos uma pesquisa com 222 alunos do curso de Formação Continuada em Língua Portuguesa, promovido pela Fundação CECIERJ em parceria com a Secretaria Estadual de Educação do Rio de Janeiro - SEEDUC. Todos os alunos são professores de Língua Portuguesa da rede estadual de ensino, matriculados no curso de extensão na modalidade EaD.

\section{REFERENCIAL TEÓRICO}

O referencial teórico contou com quatro partes específicas e bem distintas. A primeira tratou dos principais conceitos envolvidos na $\mathrm{EaD}$ e a sua expansão no Brasil via o ensino 
superior, contou com MORAN (2002), MAIA e MATAR (2007) e LEMGRUBER (2008). A segunda parte abordou a legislação brasileira pertinente sobre o tema. A seção seguinte trabalhou a docência virtual, suas competências e sua formação, que contou com os seguintes autores entre outros: PERRENOUD (2001), BOSI (2007), NÓVOA (2008), ROCHA (2008), AZEVEDO (2009), TEIXEIRA JÚNIOR (2010), MILL (2012) e BEHAR (2013). A última parte do desenvolvimento contou com argumentos sobre a graduação a distância e o desafio da qualidade, onde JULIATTO (2005) e NETTO, GIRAFFA e FARIA (2010), entre outros, trataram esta questão.

\section{METODOLOGIA}

A abordagem de investigação é de cunho qualitativo, com pesquisa documental e bibliográfica como técnicas exploratórias, onde se buscou estabelecer relações sobre a formação desse profissional que tem sobre seus ombros a missão de ensinar a distância com qualidade e responsabilidade.

Para verificar em que grau estes sujeitos da pesquisa - os cursistas consideram importante a atuação dos tutores nessa modalidade de educação, adotamos como coleta de dados um questionário com perguntas fechadas e, após a devida autorização da coordenação geral do curso, enviamos aos respectivos e-mail. Os alunos recebiam um link através do qual poderiam respondê-lo via survey online.

\section{RESULTADOS E DISCUSSÕES}

A Educação a Distância (EaD), em particular, é entendida como um processo de ensino-aprendizagem no qual alunos e professores se encontram separados espacial e/ou temporalmente, e que tem uma relação fundante com a tecnologia. Assim, emerge renovada na Era da Informação.

$\mathrm{O}$ conceito de $\mathrm{EaD}$ parece, à primeira vista, ser bem simples. Segundo os autores MAIA e MATTAR (2007, p. 6) é "uma modalidade de educação em que os professores e alunos estão separados, planejada por instituições e que utiliza diversas tecnologias de 
comunicação". MILL (2012, p. 21), por sua vez, argumenta que ela seria uma modalidade de educação geralmente considerada uma forma alternativa e complementar para a formação do cidadão, "com ricas possibilidades pedagógica e grande potencial para a democratização do conhecimento".

As possibilidades dessa modalidade se multiplicam com o uso de tecnologias digitais e de rede, gerando diferentes modelos de educação para o desenvolvimento profissional ou pessoal que requerem, ainda assim, a interação entre estudantes e docentes. MORAN (2002, não paginado) argumenta que a Educação a distância "não é um 'fast-food' em que o aluno se serve de algo pronto. É uma prática que permite um equilíbrio entre as necessidades e habilidades individuais e as do grupo - de forma presencial e virtual".

Esse autor ainda sugere um movimento no sentido de uma convergência entre a EaD e a educação presencial, gerando modelos definidos primordialmente segundo necessidades pedagógicas, mas incluindo, sempre, o compartilhamento e o diálogo entre alunos e professores (MORAN, 2002). Entretanto, as atividades de práticas de ensino desenvolvidas pelo tutor ainda se encontram imersas em situações de isolamento e desprovidas de ação reflexiva e crítica, sugerindo a necessidade de se rever uma racionalidade emancipatória nas relações pessoais e profissionais, na organização dos currículos dos cursos, nas políticas públicas e institucionais e nas próprias práticas docentes (AZEVEDO, 2009).

A educação presencial e a EaD tem seus valores e singularidades, mas considera-se que a principal diferença entre as duas é o potencial colaborativo da $\mathrm{EaD}$. As pessoas se expõem muito mais porque precisam interagir para se fazer presentes. Seus textos e demais contatos ficam registrados no Ambiente Virtual de Aprendizagem (AVA) e, se privilegiarmos o uso de ambientes coletivos, mesclados à produção individual, podemos construir uma comunidade de aprendizagem colaborativa. Nessas comunidades somos corresponsáveis pelo processo individual e do grupo: alunos, tutores e professores.

No quadro a seguir é contextualizada a mudança do paradigma e o impacto da educação online nas salas de aula. O que pode ser notado em primeiro lugar é que o professor deixou simplesmente de ser transmissor e detentor do conhecimento e foco principal da educação tradicional, passando a ser e atuar como um elemento incentivador de descobertas e auxiliar no processo de aprendizagem do aluno, este sim um elemento ativo e participativo e foco principal do processo pedagógico.

\section{Quadro 1 - Relação Educação Tradicional e Educação on-line}




\begin{tabular}{|l|l|l|}
\hline & Na educação tradicional & Com a nova tecnologia \\
\hline O professor & Um especialista & Um facilitador \\
\hline O aluno & Na educação tradicional & Com a nova tecnologia \\
\hline A ênfase educacional & Um receptor passivo & Um colaborador ativo \\
\hline A avaliação & Memorização dos fatos & Pensamento crítico \\
\hline O método de ensino & Do que foi retido & Da interpretação \\
\hline O acesso ao conhecimento & Repetição & Interação \\
\hline
\end{tabular}

Fonte: GARCIA e CORTALAZZO (1998 apud CACIQUE, 2000, p.1).

Ocorrem, ainda hoje, dificuldades sérias na aceitação da $\mathrm{EaD}$, como a sala de aula física. MORAN (2002, p.46) nos deixa claro que "desde sempre aprender está associado a ir a uma sala de aula, e lá concentrarmos os esforços dos últimos séculos para o gerenciamento da relação entre ensinar e aprender”. Portanto, é necessária uma docência a distância, que BEHRENS (1997 apud MILL, 2012, p.30) argumenta que ela seja "capaz de promover mudanças e de se comprometer com a aprendizagem significativa, problematizadora e reflexiva para a formação profissional e a construção da cidadania".

Há, porém, algumas perguntas transversais a essa temática da educação por intermédio da metodologia a distância, que se tornam preocupantes quando recordamos a entrevista concedida à Revista Carta Capital, em 14 de dezembro de 2011, pelo professor Marco Silva, que afirma: “[...] Há uma política de inclusão de computadores nas escolas, mas não há política de formação de professores para seu uso". A partir desta afirmação, podemos questionar: quem seria esse profissional que ensina na EaD? Que competências, habilidades e atitudes eles deveriam apreender em sua formação? As respostas foram buscadas e expostas nas seções seguintes.

Analisando a natureza e a dinâmica das relações pedagógicas interpessoais que se desenvolvem entre alunos/alunos e alunos/professores em um curso de formação continuada de professores mediado através de um AVA, discute-se o impacto dessas relações na qualidade da experiência nestes cursos, concluindo que a formação para a autonomia é um processo dependente de diversos fatores, incluindo a necessidade de investir na formação dos docentes que possam fundamentar a prática pedagógica (ROCHA, 2008; KUCHARSKI, 2010).

Independente da modalidade atuante, o docente é um elemento imprescindível. GATTI $(2009$, p. 2) afirma, portanto, que "o papel e a formação desse profissional, sua inserção na 
instituição e no sistema, são pontos vitais [...] a Educação para ser humano se faz em relações humanas profícuas". A autora ainda complementa ratificando que nos processos de educação a distância observa-se a importância ampla do professor, desde a criação, produção, revisão, recomposição dos materiais didáticos, até aos contatos com os alunos, mais diretos ou indiretos, em diferentes momentos, por diferentes modalidades.

No entanto, BOSI (2007) e NÓVOA (2008) sugerem que o trabalho dos tutores tem se reduzido ao de "prestadores de serviços temporários", com pagamentos através de bolsas e sem as devidas garantias legais e reconhecimentos institucionais. As condições de trabalho dos tutores são claramente ruins e resultam do acúmulo da docência virtual e presencial, bem como da dificuldade na organização de tempo e espaço para a execução da tutoria propriamente dita, da falta de diálogo entre as equipes de docentes, bem como da dificuldade de manter o ânimo dos alunos e da baixa remuneração (TEIXEIRA JÚNIOR, 2010).

No Brasil, os programas de EaD são regulamentados, avaliados e supervisionados pelo MEC, que é responsável pelo credenciamento de cursos. Isso exige um processo no qual a instituição precisa evidenciar que sua proposta de curso é consistente com os Referenciais de Qualidade (BRASIL, 2007a). O documento é flexível com relação ao desenho didático e às combinações de linguagens e recursos educacionais e tecnológicos utilizados em um curso, mas determina que é necessário contemplar-se as dimensões técnico-científica e política. A Portaria Normativa $n^{\circ} 2$ de 2007, do Ministério da Educação (BRASIL, 2007b), complementa os Referenciais em seu art. $1^{\circ}$, parágrafo segundo, que especifica os documentos necessários e comprobatórios da existência física e tecnológica e de recursos humanos necessários, consistentes com o Decreto n. 5.622/05 (BRASIL, 2005) e os Referenciais.

Ainda que não defina um modelo único de EaD, os Referenciais (BRASIL, 2007a) especificam elementos obrigatórios a serem oferecidos por todos os cursos propostos, referindo-se à organização didático-pedagógica, ao corpo docente e de tutores, além de mencionar as instalações físicas a serem disponibilizadas e utilizadas pelos alunos na universidade e em seus polos de apoio presencial. Os projetos político-pedagógicos dos cursos devem apresentar com clareza as opções do currículo, a concepção de educação, os sistemas de comunicação, o material didático, a avaliação, a composição da equipe multidisciplinar, a infraestrutura de apoio, a gestão acadêmico-administrativa, a sustentabilidade financeira, bem como o perfil do aluno que pretende formar.

Em relação ao corpo docente que integra o credenciamento das instituições atuantes nessa modalidade, deve ser apresentado um quadro de qualificação dos docentes responsáveis 
pela coordenação do curso, pela coordenação de cada disciplina, pela coordenação do sistema de tutoria e outras atividades relativas ao desenvolvimento do curso. Entretanto, relativamente pouco é dito com relação ao tutor. Assim, permanece uma lacuna importante, que permite que instituições não idôneas desvirtuem as intenções do documento através da adoção de estratégias de aumento da lucratividade sem quaisquer preocupações com a qualidade e a "identidade" do tutor (LEMGRUBER, 2008).

A docência na $\mathrm{EaD}$ ainda não está profissionalizada, é uma força de trabalho geralmente depreciada ou contratada com pouca seriedade - uma relação de tratamento ainda "inferior ao dado à docência presencial, que já não tem sido recebida de modo adequado [...] ainda se mostra diversificado, informal, temporário, precário, intensificado, sucateado, mal remunerado e desmantelado" (MILL, 2012, p.45). O professor não é descartável, nem substituível, pois, quando bem formado, ele detém um saber que alia conhecimento e conteúdos de didática e as condições de aprendizagem para segmentos diferenciados.

A perspectiva da formação docente especializada para esta modalidade exige uma reflexão sobre um "novo pensar" dos participantes, de forma ativa e crítica, bem como os seus instrumentos didáticos, práticas e projetos pedagógicos. $\mathrm{O}$ docente precisa buscar e trocar experiências, de modo a construir referenciais que orientem suas escolhas, para atingir seus objetivos pedagógicos no contexto de sua prática educativa dinâmica e contínua, podendo ser alterada pelas respostas tecnológicas e pelas práticas que surgirão no decorrer do processo de ensino-aprendizagem.

Não podemos deixar de frisar, que independente da depreciação profissional atribuída ao docente tutor, ele desempenha um papel chave no processo de ensino-aprendizagem na EaD, sinalizando o despontar de novos saberes docentes, novos comportamentos de aprendizagem e novas racionalidades, além de novas relações de trabalho que indicam transformações na categoria docente.

Os sujeitos da pesquisa, conforme já comentado, são professores de português da rede estadual de educação do Rio de Janeiro que estão fazendo uma formação continuada via EaD. Assim sendo, o instrumento de coleta, um questionário online que contou com seis perguntas fechadas, foi solicitado a entrar no link e responder 500 professores. Deste total, participaram do levantamento 222 respondentes, ou seja, 44\%. Como este é estudo qualitativo, consideramos um número muito bom para o objetivo colimado, porém, não poderemos generalizar os seus achados.

As questões foram analisadas na sequência em que foram formuladas, com análises 
pontuais e procurando fazer a relação com a $\mathrm{EaD}$ e a formação desse futuro professor-tutor.

A primeira pergunta questionava há quanto tempo trabalha como professor de Língua Portuguesa? Procurou-se ter uma ideia da experiência dos cursistas, ou seja, dos alunos que estavam realizando uma formação continuada via a distância. A Figura 1 mostra que 74\% dos respondentes têm acima de seis anos no magistério, dado importante na avaliação da amostra que estamos trabalhando.

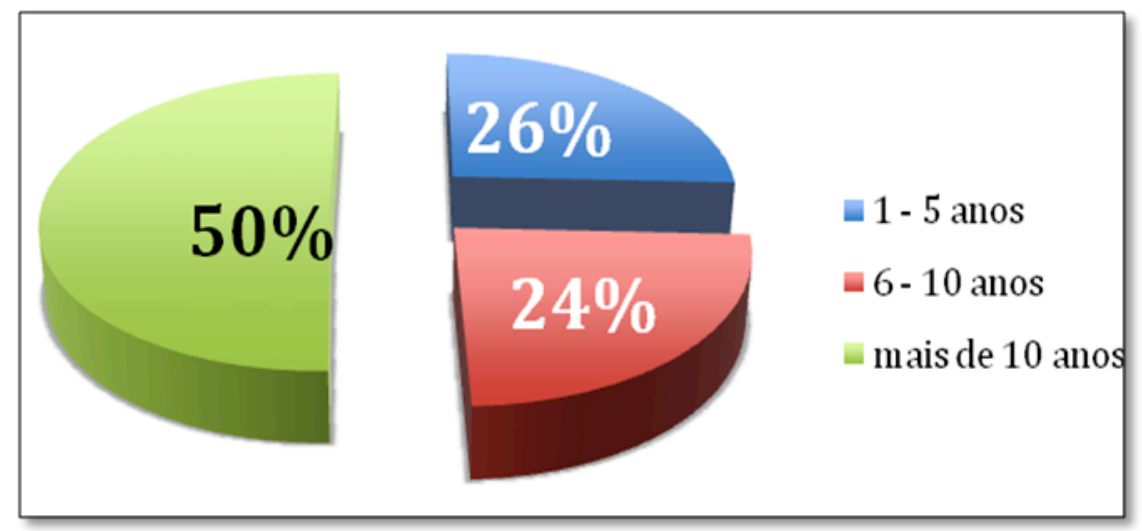

Figura 1 - A experiência profissional dos cursistas Fonte: Os autores.

A segunda questão é uma continuação da primeira, pois faz uma reflexão pessoal do cursista sobre a motivação pela formação continuada e pela metodologia a distância. A Figura 2 deixa claro que mais de $90 \%$, quase a totalidade, fez a opção por escolha própria, o que significa a grande possibilidade do curso em tela ser bem desenvolvido, principalmente no aspecto da participação dos discentes, tão importante na EaD.

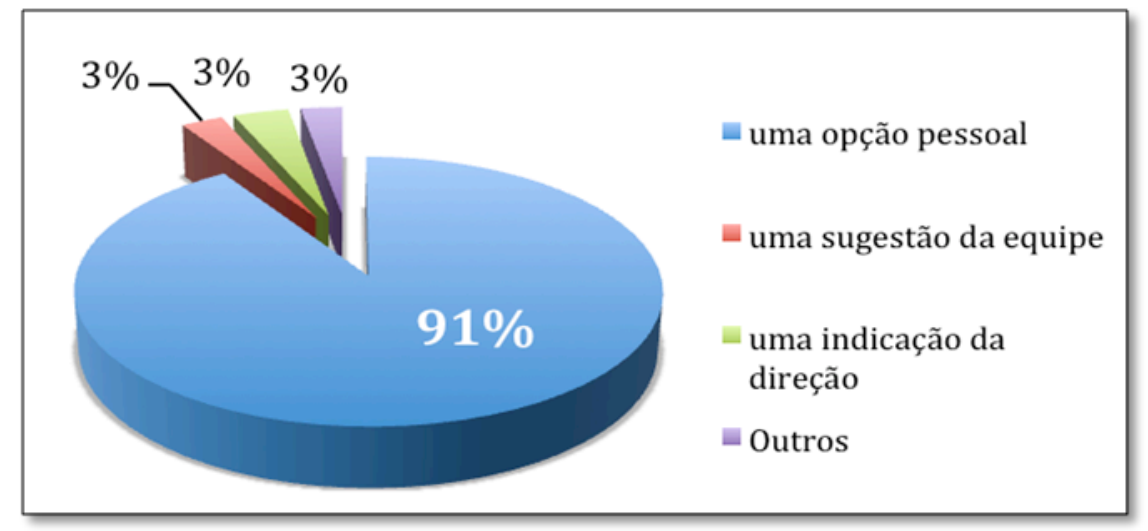

Figura 2 - Motivação para realização do curso Fonte: Os autores.

A pergunta seguinte procurou verificar um aspecto normalmente contatado durante $\mathrm{o}$ desenvolvimento de um curso a distância, quando em um determinado momento, o aluno começa a perder a motivação, tanto na participação quanto nas atividades, por inúmeros 
fatores alheios inclusive a sua vontade. É nesse momento que devemos considerar a comunicação de apoio do professor-tutor. O que o aluno cursista acha disso? A percepção dos respondentes é que quase sempre ou mesmo na maioria das vezes é verificada a efetividade dessa ferramenta, trazendo o aluno para a continuação da sua formação a distância, como mostrado na Figura 3.

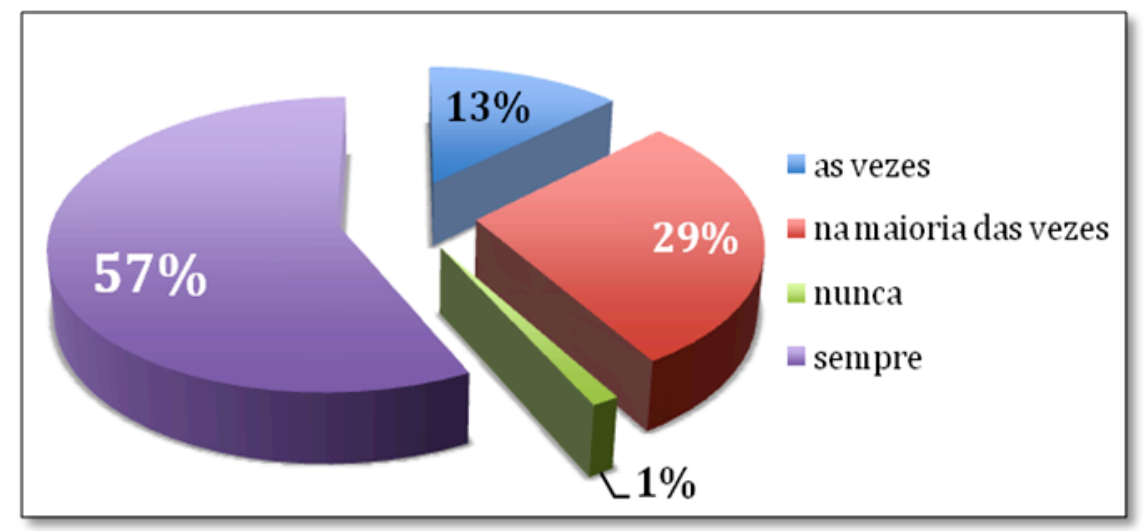

Figura 3 - Avaliação das mensagens de apoio motivacional Fonte: Os autores.

Como podemos verificar na ilustração da Figura 4, que demonstra a importância do professor-tutor na visão dos alunos cursistas. Pode-se ratificar, o que já é corroborado na afirmativa de MILL (2012), o papel desempenhado pelo tutor, pois $89 \%$ dos respondentes considera a presença do mesmo nos cursos de educação a distância muito importante.

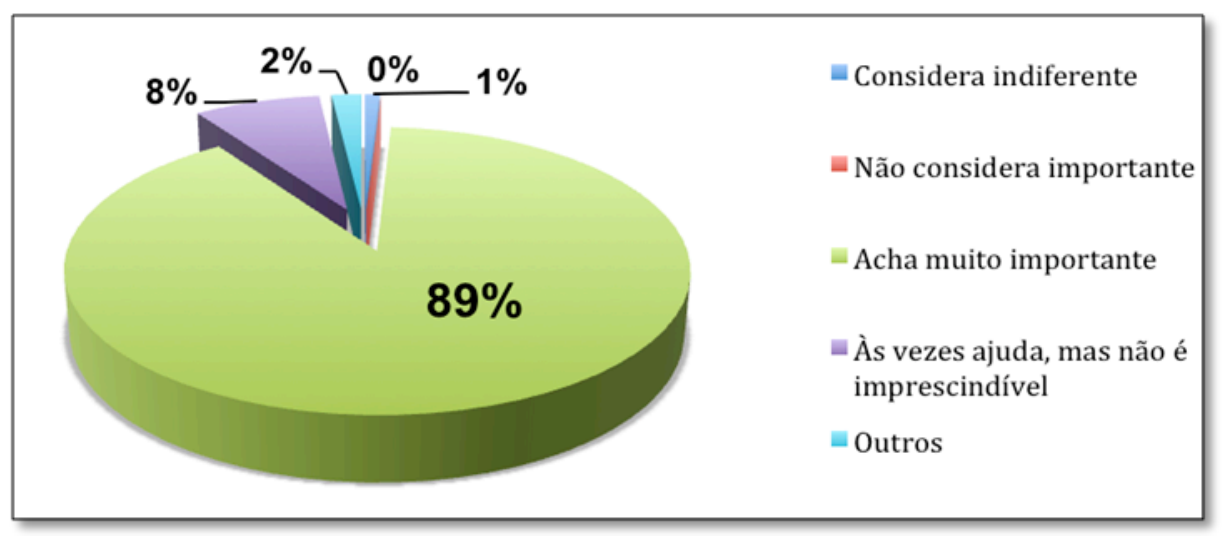

Figura 4 - Quanto ao grau de importância do tutor no curso EaD Fonte: Os autores.

Podemos então asseverar que a tutoria tem uma relação direta com o processo de ensino-aprendizagem, pois estes profissionais estabelecem um vínculo mais próximo com os 
alunos, e de grande importância na participação do desenvolvimento dos cursos e de projetos da modalidade. Uma das estratégias utilizadas pelos tutores nos cursos em EaD são as mensagens, enviadas aos cursistas ou postadas nas plataformas dos cursos, para lembrar aos cursistas sobre suas tarefas na web, numa tentativa também de diminuir a distância virtual.

Quanto a estas mensagens, $82 \%$ do grupo de entrevistados afirmaram que leem todas as mensagens, pois a consideram muito importantes. A Figura 5 deixa bem claro que em certa medida os alunos sempre leem as mensagens enviadas por seus tutores.

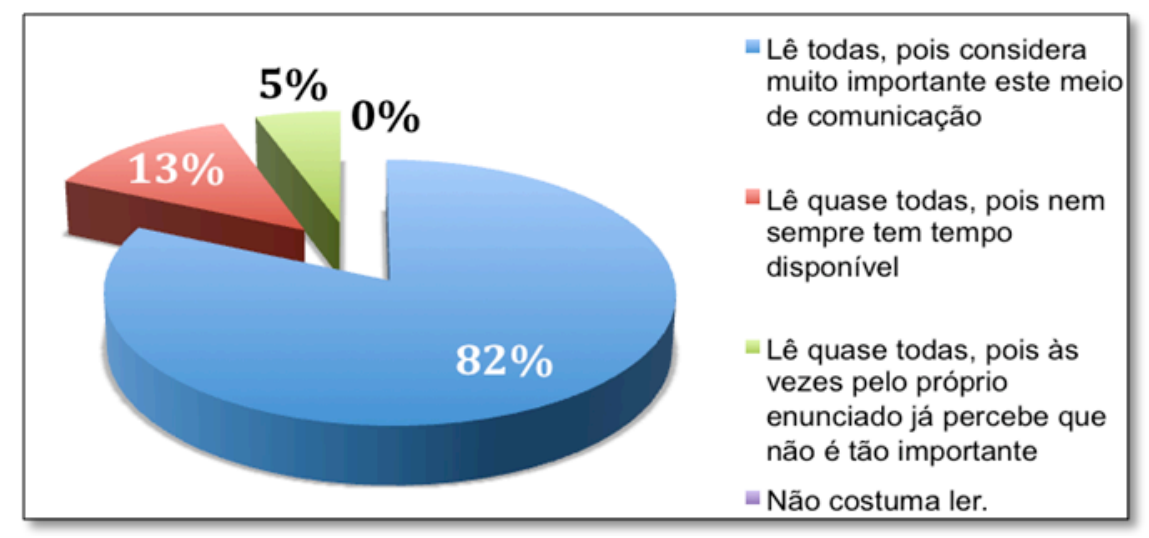

Figura 5 - Resultado das Mensagens Enviadas pelos Tutores Fonte: Os autores.

A última questão procurou apresentar um termômetro da real necessidade do tutor, principalmente em que momento o aluno se viu mais necessitado de uma comunicação mais fluente e rápida. Como as perguntas eram fechadas, também para agilizar a análise das respostas, foram ofertadas três respostas padrão: no momento de dúvidas sobre os conteúdos do curso; no momento da realização das tarefas; e durante o contato com o ambiente virtual. A Figura 6 deixa nítida a necessidade do aluno no momento da realização das tarefas, onde há a pressão pelo cumprimento de prazos e também de avaliação. 


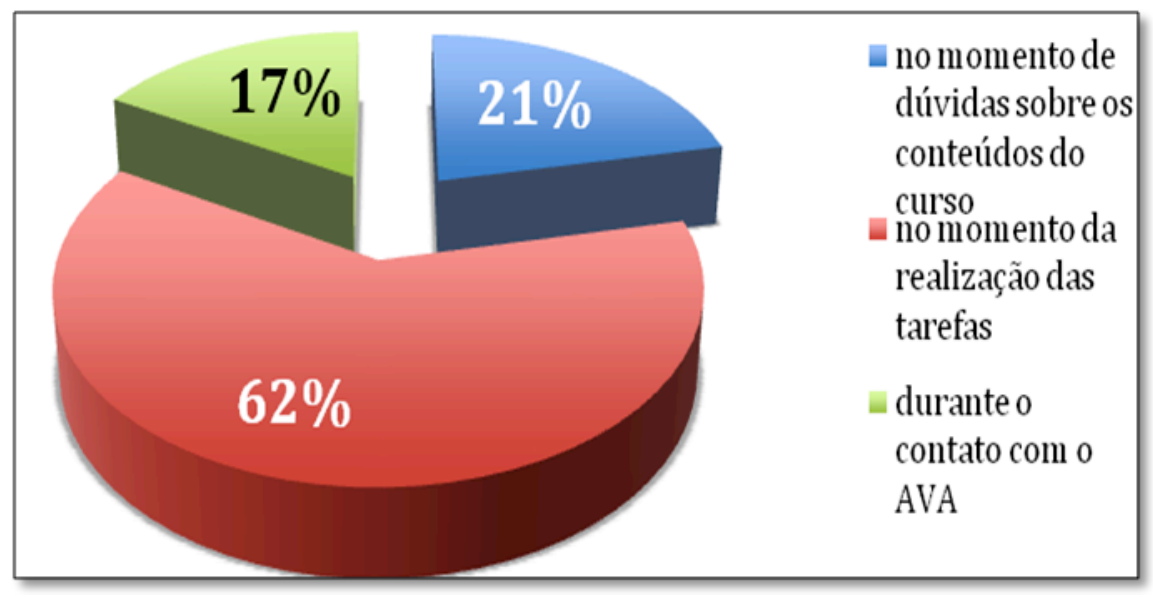

Figura 6 - Necessidade de apoio do professor-tutor Fonte: Os autores.

A formação do profissional da modalidade a distância deve se preocupar em adquirir também uma cultura básica no domínio das tecnologias, quaisquer que sejam suas práticas pessoais (PERRENOUD, 2001). Dessa maneira é privilegiada a mediação pedagógica com destaque na interação e na relação entre os participantes do processo. Ainda no sentido de manter esta relação e interação do cursista, o tutor muitas vezes, ao perceber a desmotivação do aluno, tenta através de suas mensagens motivadoras diárias recuperar a atenção deste aluno para o curso. Evidenciou-se pelas respostas expostas que, além da importante ajuda técnica, o tutor também deverá influenciar positivamente a permanência do aluno no curso.

A tríade: conhecimentos, habilidades e atitudes fundamentam a discussão de pressupostos teóricos, tecnológicos e metodológicos das competências na perspectiva da $\mathrm{EaD}$ (BEHAR, 2013). A autora aponta as características necessárias para o "novo" docente da atualidade, atuante na modalidade a distância.

Um interessante conceito de "polidocência" é exposto por MILL (2012, p.68) quando no trato desta modalidade de educação a distância, como uma nova forma de divisão do trabalho pedagógico. Numa relação entre professor coordenador da disciplina, do professor que prepara o material de estudo, ou conteudista, e o professor-tutor, que tem ligação direta com os alunos, genericamente, seria uma docência coletiva, "pressupondo uma equipe colaborativa e fragmentada, em que cada parte é realizada por um trabalhador distinto".

$\mathrm{O}$ que corrobora a ideia de que em $\mathrm{EaD}$ a docência não é um empreendimento individual, em grande parcela por causa da complexidade das tecnologias nas quais se apoia o trabalho virtual (MILL, 2012, p.30), e desta forma, ratifica que o docente virtual, um sujeito integrante de um coletivo, é um elemento imprescindível no trato das relações professor- 
professor-tutores-tutores-alunos-alunos-professores, em uma comunicação de "todos-todos".

Além das reflexões anteriores, a qualidade deve estar presente no âmbito educacional. Os chamados "indicadores de qualidade" são características ou aspectos convergentes que compõem uma estrutura básica, agrega valores que reafirmam a qualidade da instituição em relação a sua estrutura (JULIATTO, 2005). Para o autor, esses indicadores não são estáticos, pois se modificam em função do tempo, servindo como elementos que avaliam e levantam medidas a respeito dos aspectos objetivos de qualidade. Este conceito, mesmo não sendo utilizado de forma global, existe e evidencia uma preocupação mundial com resultados educacionais que buscam a qualidade na educação. (JULIATTO, 2005; NETTO, GIRAFFA, FARIA, 2010)

\section{CONSIDERAÇÕES FINAIS}

Independente da depreciação profissional atribuída ao docente tutor, ele desempenha um papel imprescindível no ensino-aprendizagem na EaD, sendo, antes de tudo, o papel ocupado por um professor, que ao longo de sua trajetória docente, vem aprimorando maiores habilidades para o seu desempenho no ambiente virtual. Ele é profissional que amplia cada vez mais o seu repertório de estratégias pedagógicas, sinalizando o despontar de novos saberes docentes, novos comportamentos de aprendizagem e novas racionalidades, além de novas relações de trabalho.

Após análise da pesquisa, podemos afirmar que sob a ótica deste grupo de cursistas, fica claro que o tutor desempenha um papel fundamental na esfera de acompanhamento virtual, sendo a ele atribuído mérito e importância, não somente no momento da realização das atividades, como também quando atua no contexto da motivação, ao incentivar os cursistas quando estes se apresentam desanimados para continuar no curso.

Ainda segundo os entrevistados, o tutor é aquele que articula o desenvolvimento virtual na busca de saberes, possibilitando a construção coletiva de novos olhares sobre o conhecimento, através da organização de fóruns de debates e do incentivo à participação em chats. Neste sentido, acreditamos que o despertar da reflexão crítica entre os participantes virtuais seja o grande desafio da função docente representada, neste caso, pelo tutor.

Além das dimensões motivacionais para a construção dos conhecimentos, os 
entrevistados destacam ainda a importância do tutor na abordagem metodológica da Educação a Distância, ou seja, na parte mais operacional de como buscar as informações e executar tarefas dentro do novo ambiente virtual.

É importante enfatizarmos também que o campo da EaD no Brasil é muito extenso, e ainda necessita de pesquisas que aprofundem essa temática sob óticas e espaços distintos. Não obstante, no cenário da tutoria muito temos ainda que caminhar no sentido de melhorarmos a capacitação dos tutores e de elevarmos essa profissão ao seu devido prestigio.

\section{REFERÊNCIAS}

AZEVEDO, M. A. R. Os Saberes de Orientação dos Professores Formadores: Desafios para Ações Tutorais Emancipatórias. São Paulo: USP, 2009.

BEHAR, P. A. Competências em educação a distância. São Paulo: Pensar, 2013.

BOSI, A. de P. A precarização do trabalho docente nas instituições de ensino superior do Brasil nesses últimos 25 anos. Educação \& Sociedade, v. 28, n.101, set/dez.2007, p.1503-1523. Disponível em: <http://www.cedes.unicamp.br> Acesso em: 14 abr. 2013.

BRASIL. Presidência da República. Decreto n. 5.622 de 19 de dezembro de 2005. Regulamenta o art. 80 da Lei n. 9.394, de 20 de dezembro de 1996, que estabelece as diretrizes e bases da educação nacional. Publicação eletrônica. Brasília, DF, 2005. Disponível em: $<$ https://www.planalto.gov.br//legislações/leis>. Acesso em: 08 out. 2008.

BRASIL. Ministério da Educação. SEED. Referenciais de Qualidade para Educação a Distância. 2007a. Disponível em: <http://portal.mec.gov.br/seed/arquivos/pdf/referenciaisead.pdf>. Acesso em: 17 abr. 2012.

BRASIL. Ministério da Educação. Portaria n. 02, de 10 de janeiro de 2007. Dispõe sobre os procedimentos de regulação e avaliação da educação superior na modalidade a distância. 2007b. Disponível em: <http://portal.mec.gov.br/seed/arquivos/pdf/legislacao/portaria2.pdf>. Acesso em: 22 jul. 2015.

CACIQUE, A. Educação a distância: uma experiência comparativa entre o ensino presencial e via internet. Revista Educação e Tecnologia, Belo Horizonte, v. 5, n. 2, p. 4-51, jul./dez. 2000. Disponível em: < http://www2.cefetmg.br/dppg/revista/arqRev/revistan5v2-artigo7.pdf >. Acesso em: 22 dez 2008.

GATTI, B. A. Formação de professores: condições e problemas atuais. Revista Brasileira de Formação de Professores, v. 1, n. 1, p. 90-102, maio, 2009. Disponível em: $<$ http://www.facec.edu.br/seer/index.php/formacaodeprofessores/article/view/20/65>. Acesso em: 7 mai. 2013. 
GIDDENS, A. Mundo em Descontrole: o que a globalização está fazendo de nós. Rio de Janeiro: Record, 2003.

JULiATTO, C. I. A. Universidade em Busca da Excelência: um estudo sobre a qualidade da Educação. 2. ed. Curitiba: Universitária Champagnat, 2005.

KUCHARSKI, M. V. S. Relações Interpessoais em um ambiente virtual de aprendizagem: etnografia virtual de uma (des)construção. 2010. 263 f. Tese (Doutorado em Educação). Pontifícia Universidade Católica do Paraná, Curitiba, 2010.

LEMGRUBER, M. S. Educação a Distância: para além dos caixas eletrônicos. Pernambuco. In: $2^{\circ}$ Simpósio Hipertexto e Tecnologias na Educação, Anais..., 2008. Disponível em: < http://portal.mec.gov.br/arquivos/conferencia/documentos/marcio_lemgruber.pdf $>$. Acesso em: 18 abr. 2012.

MAIA, C.; MATTAR, J. ABC da EAD: a educação a distância hoje. São Paulo: Pearson Prentice Hall, 2007.

MILL, D. Docência Virtual: uma visão crítica. Campinas, SP: Papirus, 2012. (Coleção Papirus Educação).

MORAN, J. M. O que é educação à distância. 2002. Disponível em: $<$ http://www.eca.usp.br/prof/moran/dist.htm>. Acesso em: 22 ago. 2013.

NETTO, C., GIRAFFA. L.; FARIA, E. Graduações a distância e o desafio da qualidade. Porto Alegre: EDIPUCRS, 2010.

NÓVOA, A. Os professores e o "novo" espaço público da educação. In: TARDIF, M.; LESSARD, C. (Org.). O ofício de professor: história, perspectivas e desafios internacionais. Petrópolis, RJ: Vozes, 2008.

PERRENOUD, P. Dez novas competências para uma nova profissão. Revista Pedagógica, v.5, n.17, p.8-12, maio/jul. Porto Alegre: 2001.

ROCHA, A. C. A construção da autonomia na aprendizagem: a visão de alunos e tutores de curso online. 2008. 175 f. Dissertação (Mestrado em Educação) - Universidade Estácio de Sá, Rio de Janeiro. 2008.

SILVA, M. Falta interatividade. Revista Carta Capital. Entrevista publicada em 15 dez. 2011. Disponível em: <http://www.cartacapital.com.br/carta-na-escola/falta-interatividade/> Acesso em: 26 ago. 2015.

TEIXEIRA JÚNIOR, W. As condições de trabalho da tutoria virtual na educação superior no interior: vozes dos tutores. 2010. Relatório de Pesquisa. Ponta Porã, MS: Universidade Federal do Mato Grosso do Sul. In: CONGRESSO INTERNACIONAL DE EaD - ABED. 2010. Disponível em: $<$ http://www.abed.org.br/congresso2010/cd/252010152735.pdf.> Acesso em: 27 maio 2012.

RECEBIDO EM: 29/03/2016

APROVADO PARA PUBLICAÇÃO EM: 29/11/2016 